\title{
PENGUATAN LITERASI MATEMATIKA DAN JIWA KEWIRAUSAHAAN MELALUI MATRIKULASI
}

\author{
Alpha Galih Adirakasiwi \\ Universitas Singaperbangsa Karawang, Indonesia \\ alpha.galih@fkip.unsika.ac.id
}

\begin{abstract}
Community service activity aims through this matriculation is to improve the ability of mathematical literacy and entrepreneurial spirit of vocational students. The method used in this activity is through pretest, giving material and practice questions, posttest and finally evaluation of activities. The result of this activity is an increase in students' mathematical literacy skills and entrepreneurial spirit by $43.72 \%$. based on the level of entrepreneurial spirit at level 1 - Employee (Littele Risk).
\end{abstract}

Keywords: student literacy, entrepreneurial spirit, matriculation

\begin{abstract}
Abstrak
Kegiatan pengabdian masyarakat bertujuan melalui matrikulasi ini adalah untuk meningkatkan kemampuan literasi matematis dan jiwa kewirausahaan siswa SMK. Metode yang digunakan dalam kegiatan ini melalui pretest, pemberian materi dan latihan soal, postest dan terakhir evaluasi kegiatan. Hasil dari kegiatan ini adalah meningkatnya kemampuan literasi matematis dan jiwa kewirausahaan siswa sebesar $43.72 \%$. berdasarkan level jiwa kewirausahaan berada pada level 1 - Employee ( Littele Risk).
\end{abstract}

Kata Kunci: literasi mahasiswa, jiwa kewirausahaan, matrikulasi

\section{Pendahuluan}

Peraturan Menteri Pendidikan dan Kebudayaan Nomor 23 Tahun 2015 tentang Penumbuhan Budi Pekerti. Permendikbud ini kemudian menginisiasi lahirnya Gerakan Indonesia Membaca dan Gerakan Literasi Sekolah. Fokus Pemerintah bukan hanya sekedar membuat siswa bisa calistung (membaca, menulis dan berhitung), melainkan mendorong siswa paham materi yang dibaca dan dipelajarinya. Pernyataan ini sesuai dengan literasi yang digunakan oleh PISA.

Dalam studi PISA ada empat konteks yang menjadi fokus, yaitu: konteks pribadi (personal), konteks pekerjaan (occupational), konteks sosial (social) dan konteks ilmu pengetahuan (scientific) (OECD, 2013). Salah satu yang menjadi fokus kegiatan abdimas ini adalah konteks pekerjaan dan ilmu pengetahuan. Konteks pekerjaan berkaitan dengan kehidupan siswa di sekolah dan atau tempat lingkungan siswa bekerja. Literasi matematika diharapkan dapat membantu untuk merumuskan, melakukan klasifikasi masalah, dan memecahkan masalah tersebut.

Jiwa kewirausahaan termasuk ke dalam konteks pekerjaan. Kewirausahaan adalah salah satu alternatif bagi masyarakat untuk mengatasi masalah pengangguran dan kemiskinan. Hal tersebut didasarkan dari pengertian kewirausahaan yaitu Kewirausahaan merupakan kemampuan seseorang yang berinti pada pemikiran kreatif dan tindakan inovatif yang dijadikan dasar, kiat dan sumber daya untuk memecahkan masalah dan 
menciptakan peluang agar meraih sukses dalam berusaha atau hidup. Selain itu, Marvin \& Flora (2014) juga menyatakan bahwa kewirausahaan dapat mendorong perekonomian dan memiliki manfaat dalam menciptakan lapangan pekerjaan bagi orang yang tidak dapat bekerja baik pada lembaga pemerintahan maupun perusahaan swasta.

Pentingnya kewirausahaan sebagai solusi alternatif bagi masalah pengangguran dan kemiskinan ini membuat pemerintah mengeluarkan Instruksi Presiden Nomor 4 Tahun 1995 dan membuat suatu Visi Kementerian Pendidikan Nasional Tahun 2014. Dari dasar inilah pendidikan kewirausahaan diterapkan pada kurikulum pendidikan mulai dari jenjang pendidikan dasar maupun pendidikan menengah. Salah satu wujud nyata dari hal ini adalah dilaksanakannya pendidikan kewirausahaan khususnya di Sekolah Menengah Kejuruan (SMK). Seperti di SMK Wirasaba mata pelajaran kewirausahaan wajib dipelajari oleh siswa kelas $X$ pada semua jurusan. Siswa dituntut untuk dapat mengembangkan produk hasil rumahan yang dapat dijadikan lapangan pekerjaan. Sayangnya, produk kewirausahaan hanya sebatas tugas akhir yang digunakan untuk penambahan nilai ujian. Seperti pada gambar di bawah ini hasil karya siswa
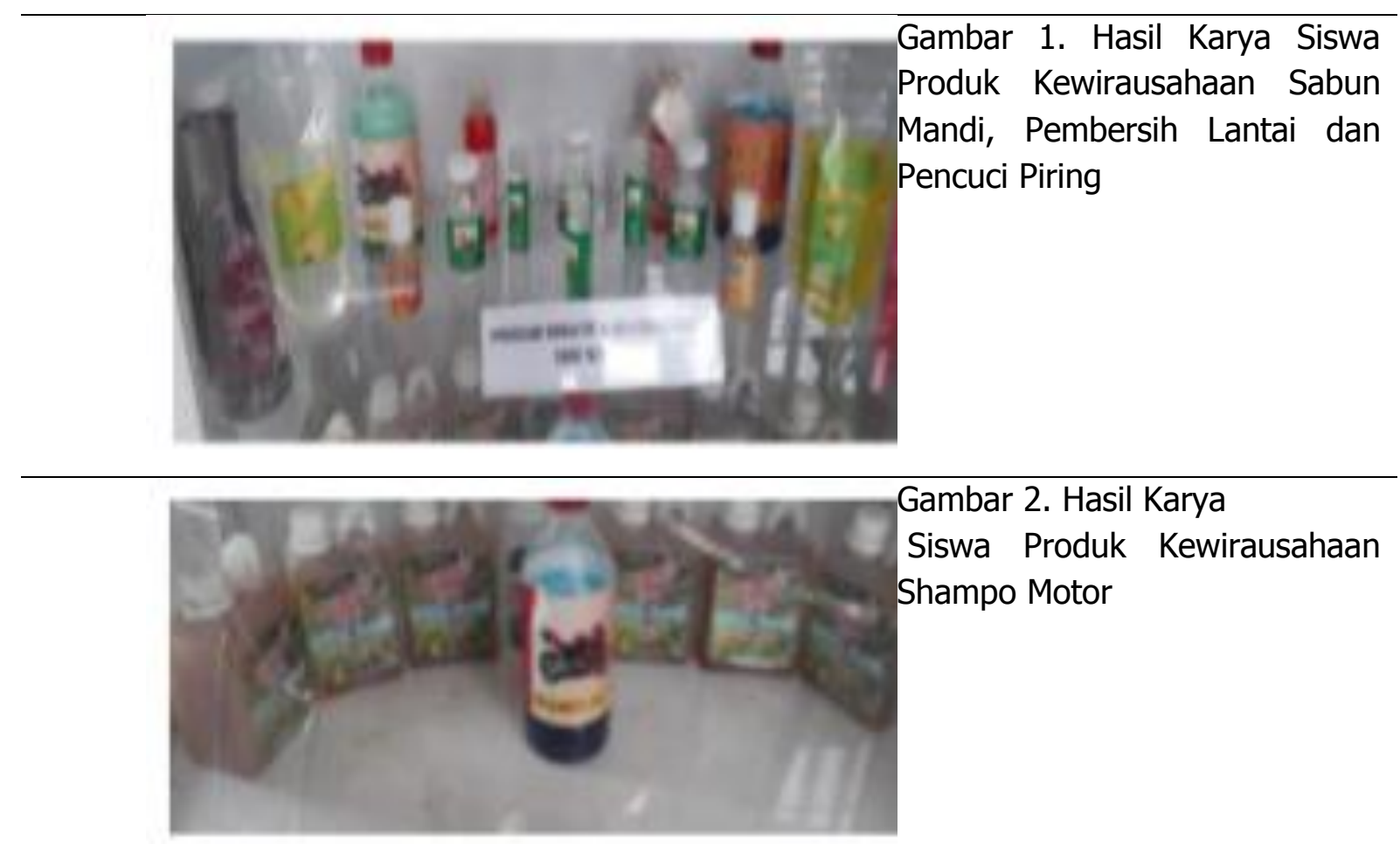

Gambar 2. Hasil Karya

Siswa Produk Kewirausahaan Shampo Motor

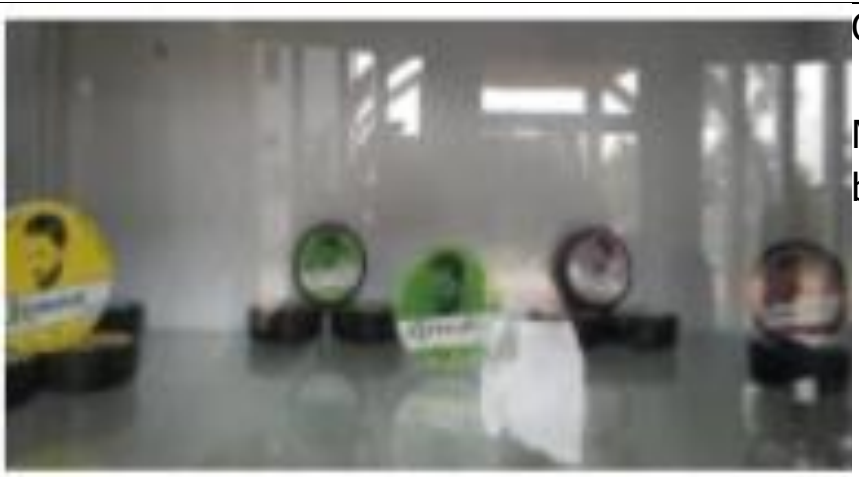

Gambar 3. Hasil Karya

Siswa Produk Kewirausahaan Minyak Rambut dengan berbagai Varian Rasa 
Salah satu cara untuk mengatasi permasalahan di atas adalah dengan kegiatan matrikulasi. Kegiatan matrikulasi penguatan literasi matematika dan jiwa kewirausahaan bagi kelas XI sebagai upaya program yang mempunyai sisi positif bagi siswa-siswi dalam peningkatan mutu pembelajaran (Ali, 2014). Kegiatan matrikulasi penting dilaksanakan sebagai respon atas fakta-fakta yang ada demi terwujudnya proses pembelajaran yang mudah.

Luaran yang hendak dicapai dalam kegiatan ini yaitu meningkatkan literasi matematika dan jiwa kewirausahaan melalui matrikulasi dengan tahapan memberikan sosialisasi kepada orangtua dan siswa, tujuan dan manfaat kegiatan, pemberian pretes, pemberian materi tambahan seperti latihan soal-soal dan penambahan materi wawancara berdasarkan level jiwa kewirausahaan, posttes dan evaluasi. Diharapkan melalui wawancara dapat dijdaikan dasar dan pengatahuan kewirausahaan, melalui produk kreatif dan kewirausahaan dapat dikembangkan menjadi usaha mandiri. Pendahuluan menguraikan latar belakang permasalahan yang diselesaikan, isu-isu yang terkait dengan masalah yg diselesaikan, ulasan penelitan/pengabdian yang pernah dilakukan sebelumnya oleh peneliti/pengabdi lain yg relevan dengan penelitian/pengabdian yang dilakukan.

\section{Metode}

Metode yang akan digunakan pada kegiatan pengabdian adalah matrikulasi. Adapun tujuan kegiatan matrikulasi bertujuan pada dasarnya untuk mencapai entry level yang sama bagi seluruh siswa berisi pemantapan materi yang harus dikuasai.

Adapun alur pelaksanaan kegiatan matrikulasi dijelaskan secara terperinci sebagai berikut: 1) Sosialisasi kepada orangtua dan siswa; 2) Tujuan kegiatan dan manfaat kegiatan, Matrikulasi memberikan kesempatan kepada siswa untuk menyetrakan pengetahuan literasi matematika dan jiwa kewirausahaan di mulai dari usia sekolah. Melalui kegiatan ini, siswa bukan hanya mampu memahami dan menguasai pengetahuan tetapi juga memiliki bekal yang sama dalam literasi matematika dan jiwa kewirausahaan; 3) Pemberian pretes, Tes awal atau Pretes dilaksanakan sebelum matrikulasi dilakukan unuk melihat sejauh mana pemahaman siswa dalam literasi matematika; 4) Pemberian materi tambahan literasi matematika secara intesif dan latihan soal-soal PISA yang menjadi tolak ukur literasi matematika dan penambahan materi jiwa kewirausahaan serta melakukan wawancara berdasrakan indikator level jiwa kewirausahaan; 5) Pemberian posttes dilaksanakan setelah matrikulasi dilakukan untuk meliha sejauh mana kemajuan yang telah dicapai pada kegiatan matrikulasi ini; 6) Evaluasi dilakukan secara kumulatif dalam bentuk nilai tes awal dan tes akhir siswa setelah mengikuti matrikulasi. Berikut diagram alir kegiatan matrikulasi 


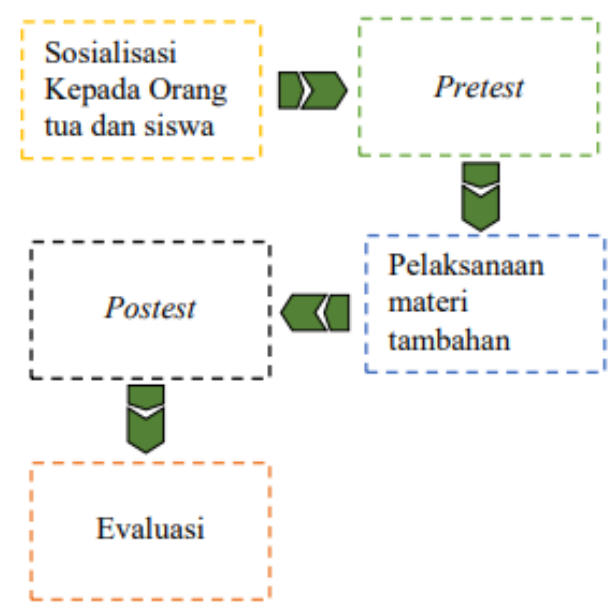

Gambar 4. Diagram Alir Kegiatan Matrikulasi

Metode-metode yang digunakan dalam penyelesaian pelaksanaan pengabdian kepada masyarakat dituliskan di bagian ini. Bagian ini memuat khalayak sasaran, lokasi kegiatan, metode yang digunakan, evaluasi kegiatan, materi kegiatan. Bagian ini juga berisi informasi yang lengkap bagi pembaca bila ingin melakukan hal yang sama. Bahan yang digunakan harus dijelaskan asalnya dan kuantitasnya. Cara kerja dan analisa data harus ditulis secara jelas dan ringkas. Modifikasi dan cara kerja yang pernah dipublikasikan cukup menyebut sumbernya dan menjelaskan bagian yang dimodifikasi.

\section{Hasil dan Pembahasan}

Kegiatan Pengabdian Masyrakat dilakukan dengan matrikulasi. Skor pretes digunakan untuk mengetahui kemampuan literasi matematis siswa. Berikut akan disajikan analisis statistik deskriptif dari data pretes kedua kelas adalah sebagai berikut :

Tabel 1 Pretes Kemampuan Literasi Matematis Siswa

\begin{tabular}{lcc}
\hline \multirow{2}{*}{ Skor } & \multicolumn{2}{c}{ Kemampuan Literasi Matematis Siswa } \\
\cline { 2 - 3 } & $\overline{\mathrm{x}}$ & $\mathrm{s}$ \\
\hline Pretes & $\begin{array}{c}9,109 \\
(20,24 \%)\end{array}$ & 6,570
\end{tabular}

Keterangan : Skor ideal untuk kemampuan Literasi matematis adalah 45

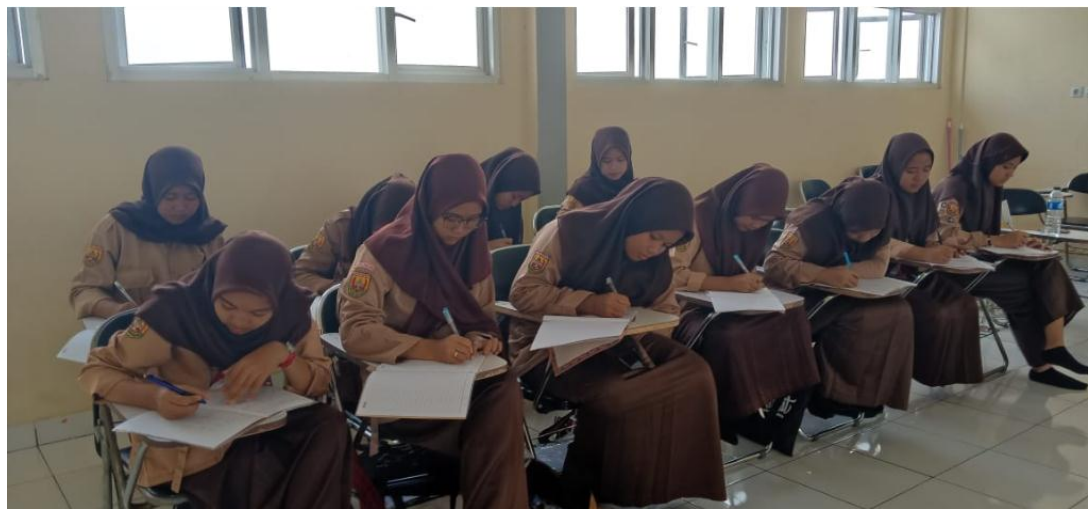

Gambar 5. Siswa diberikan Soal Pretes 
Setelah dilakukan pretes, kegiatan selanjutnya pemberian materi dan latihan-latihan SOAL PISA. Materi tambahan dilakukan setelah pulang sekolah dengan durasi 60 menit sebanyak 5 kali pertemuan dimulai dari bulan September sampai November. Pada pertemuan pertama siswa diberikan materi statistika sesuai dengan konten PISA. Pertemua kedua siswa masih banyak yang belum terbiasa dengan soal PISA, perlu adanya penjelasan untuk menyelesaikan soal PISA. Pertemuan ketiga dan keempat siswa berikan materi peluang serta tambahan soal PISA. Pertemuan kelima setelah pemberian materi dilakukan posttes. Hasil posttes disajikan pada table dibawah ini.

Tabel 2 Posttes Kemampuan Literasi Matematis Siswa

\begin{tabular}{|c|c|c|}
\hline \multirow[t]{2}{*}{ Skor } & $\begin{array}{l}\text { Kemampuan } \\
\text { Siswa }\end{array}$ & Literasi Matematis \\
\hline & $\overline{\mathrm{x}}$ & $\mathrm{s}$ \\
\hline Posttes & $\begin{array}{l}28,783 \\
(63,96 \%)\end{array}$ & 6,992 \\
\hline
\end{tabular}

Keterangan : Skor ideal untuk kemampuan Literasi matematis adalah 45

Tabel 3 di atas menunjukkan bahwa rerata pretes dan posttes kemampuan literasi matematis siswa pada kelas $X$ secara rata-rata meningkat dari 9,109 menjadi 28,783. Kenaikan dengan sebesar 19,674 atau sebesar $43.72 \%$.

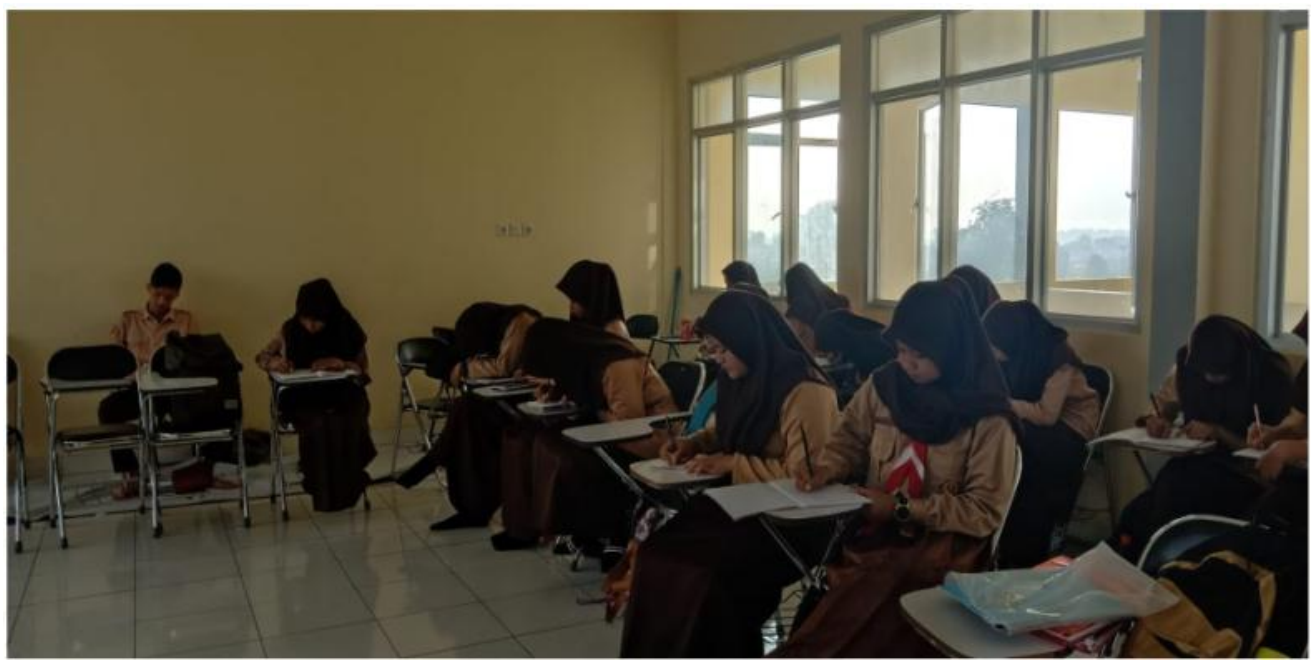

Gambar 6. Siswa diberikan Soal Postes

Tabel 3. Pretes dan Postes

Kemampuan Literasi Matematis Siswa

\begin{tabular}{cccc}
\hline \multirow{2}{*}{$\mathrm{N}$} & $\begin{array}{c}\text { Data } \\
\text { Statistik }\end{array}$ & Pretes & Postes \\
\hline \multirow{3}{*}{46} & $\overline{\mathrm{x}}$ & $\begin{array}{c}9,109 \\
(20,24 \%)\end{array}$ & $\begin{array}{c}28,783 \\
(63,96 \%)\end{array}$ \\
\cline { 2 - 4 } & $\mathrm{s}$ & 6,570 & 6,992 \\
\hline
\end{tabular}

Tabel 3 di atas menunjukkan bahwa rerata pretes dan posttes kemampuan literasi matematis siswa pada kelas X secara rata-rata meningkat dari 9,109 menjadi 28,783. 
Kenaikan dengan sebesar 19,674 atau sebesar 43.72\%. Mengetahui level jiwa kewirausahaan siswa melakukan wawancara. Berikut hasil disajikan pada tabel dibawah ini.

Tabel 4. Level Jiwa Kewirausahaan Siswa

\begin{tabular}{lc}
\hline Level Jiwa Kewirausahaan & Jumlah Siswa \\
\hline Level 1- Employee (Little Risk) & 46 \\
\hline Level 2 - Self Business or (Self & 0 \\
Employee) & \\
\hline Level 3 - Self Businessman or \\
(Business Owner)
\end{tabular}

Berdasarkan hasil wawancara yang dibuat dari pedoman wawancara yang disusun berdasarkan indikator level jiwa kewirausahaan menurut Hendro dan Widhianto (Supriatna dan Supartono, 2017), mayoritas siswa menempati Level 1 - Employee (Little Risk). Walaupun demikian terdapat juga siswa yang memiliki cikal bakal pada level yang lebih tinggi yaitu Level 2 - Self Business or (Self Employee), dan Level 3 - Self Businessman or (Business Owner). kegiatan selanjutnya adalah kegiatan evaluasi. Dari beberapa tahapan kegiatan matrikulasi yang dilakukan terdapat beberapa catatan temuan penelitian sepertinya instrumen tes untuk mengetahui level jiwa kewirausahaan.

\section{Kesimpulan}

Hasil dari kegaiatan abdimas adalah meningkatnya kemampuan literasi matematis dan jiwa kewirasusahaan melalui matrikulaasi dilihat berdsarkan hasil pretes dan postes dengan kenaikan sebesar $43.72 \%$. berdasarkan level jiwa kewirausahaan berada pada level 1 - Employee ( Littele Risk).

\section{Daftar Pustaka}

Ali, M. (2014). Strategi Manajemen Mutu Pelajaran Bahasa Arab Melalui Program Matrikulasi di Madrasah Aliyah Darut Taqwa Sengonagung Pasuruan. Jurnal Review Pendidikan Islam, 1(1), 41-53.

Permendikbud (2015). Peraturan Menteri Pendidikan Dan Kebudayaan Nomor 24 Tahun 2015 Tentang Penumbuhan Budi Pekerti

Marvin, M. E., \& Flora, T. P. C. (2014). "An Investigation of Students' Readiness Towards Entrepreneurial Intentions at Kigali Independent University (ULK)". International Journal of Education and Research, Volume 2 No. 10. Hal 263-276

OECD. 2013. PISA 2012 Results: What Students Know and Can Do Student Performance in Mathematics, Reading and Science (Volume 1). PISA, OECD Publishing.

OECD. 2013. PISA 2012 Assessment and Analytical Framework Mathematics, Reading, Science, Problem Solving and Financial Literacy. PISA. OECD Publishing. 
Supriatana, Hendra. Supartono. (2017). Kemampuan Literasi Matematika dan Jiwa Kewirausahaan pada Pembelajaran Matematika Problem Based Learning Berpendekatan Entrepreneurial Pedagogy. Unnes Journal of Mathematics Education Research 6(1) h/m 1-10 